\title{
РОЗВИТОК РИНКУ ЛІЗИНГОВИХ ПОСЛУГ В УКРАЇНІ
}

\section{THE UKRAINIAN LEASING SERVICES MARKET DEVELOPMENT}

удк 336.645.1

https://doi.org/10.32843/infrastruct37-88

\section{Ляхова О.о.}

к.е.н., доцент,

доцент кафедри корпоративних

фрінансів і контролінгу

ДВНЗ «Київський національний

економічний університет

імені Вадима Гетьмана»

Урванцева С.В.

к.е.н., доцент кафедри корпоративних

фрінансів і контролінгу

ДВНЗ «Київський національний

економічний університет

імені Вадима Гетьмана»

\begin{abstract}
У статті розглянуто лізинг як інструмент стимулювання інвестиційної активності підприємства. У прочесі дослідження застосовано загальнонаукові методи пізнання, а саме методи системного підходу, аналізу й синтезу, логічного узагальнення. Визначено, що ринок лізингових послуг поєднав елементи ринку реальних активів та фрінансового ринку. Досліджено сучасний стан розвитку ринку лізингових послуг в Україні (в розрізі основних надавачів лізингових послуг, об'єктного складу ринку, галузей-лізингоотримувачів, джерел фрінансування діяльності лізингових компаній). Основну увагу приділено аналізу впливу економічних викликів минулих років на лізингову галузь, висхідних та низхідних трендів показників розвитку ринку за 2015-2018 рр. Визначено основні проблеми й подальші перспективи розвитку вітчизняного ринку лізингових послуг. Запропоновано нормативно-правові, організаційні та фрінансові важелі впливу на активізацію діяльності учасників лізингового бізнесу. Ключові слова: лізинг, інвестиційна діяльність, фрінансова послуга, фрінансовий лізине, ринок лізингових послуг, лізингодавець, лізингоотримувач.
\end{abstract}

В статье рассмотрен лизинг как инстру мент стимулирования инвестиционной активности предприятий. $B$ прочессе исследования использованы общенаучные методы познания, а именно методы системного подхода, анализа и синтеза, логического обобщения. Определено, что рынок лизинговых услуг соединил элементы рынка реальных активов и финансового рынка. Исследовано современное состояние развития рынка лизинговых услуг в Украине (в разрезе основных лизингодателей, объектного состава рынка отраслей-лизингополучателей, источников финансирования деятельности лизинговых компаний). Основное внимание уделено анализу влияния экономических вызовов прошлых лет на лизинговую отрасль, восходящих и нисходящих трендов показателей развития рынка за 20152018 г2. Определены основные проблемы и дальнейшие перспективы развития отечественного рынка лизинговых услуг. Предложены нормативно-правовые, организационные и фринансовые рычаги воздействия на активизацию деятельности участников лизингового бизнеса.

Ключевые слова: лизинг, инвестиционная деятельность, фринансовая услуга, финансовый лизинг, рынок лизинговых услуг, лизингодатель, лизингополучатель.

The article considered leasing as a tool to stimulate an enterprise investment activity. It is determined that the leasing market combines elements of the real assets market and the financial market, in other words it can be said that long-term financial and credit relations in leasing area are transformed into monetary relations and completed in the real assets market. The article investigates the current state of the leasing services market development in Ukraine. Main attention is paid to analysis of the impact of economic challenges on leasing industry which took place during the period from 2015 to 2018 , and relevant upward \& downward trends in this market. Analysis of the economic challenges impact on the leasing industry which had place during several last years and indicators of the leasing services market development allowed to establish the following trends: a) the vast majority of operations in the leasing market are represented by a financial lease, which is carried out by three main providers: banks, financial companies and legal entities; $b$ ) main sectors of the leasing market are transport, agriculture, services and construction; c) bank loans and own funds prevail among financing sources of lessor activities, at the same time budgetary funds and issue of securities are not actually used as sources of financing for leasing services; d) considering a number of financial leases concluded and their value, a slow market recovery is observed after sharp drop in the number of leases in 2015; e) rapid development of the leasing market and doubling a Ukrainian business financing volume under financial leasing agreements by 2021 is a medium-term prospect. The study results substantiate measures to activate the leasing services market with their distribution in the following areas: improvement of the legal framework in the leasing sphere, reduction of the number of regulatory and supervisory bodies in the domestic market of financial services, unification of state regulation and supervision, development and implementation of the state leasing program, development of typical provisions for organizational structure of leasing companies and managing their risks, improving the structure of financing sources for leasing operations.

Key words: leasing, investment activity, financial service, financial leasing, market of leasing services, lessor, lessee.

Постановка проблеми. Ринок лізингових послуг відіграє суттєву роль в русі капіталу, забезпечує економічне оновлення й зростання виробництва, а також підвищення конкуренції в межах ринку фрінансових послуг. 3 початку реформ і по теперішній час процеси перетворень, що протікають на ринку лізингових послуг, не $є$ односпрямованими й однозначними. Їх висока динамічність обумовлює необхідність комплексного розгляду лізингового ринку, що робить тему актуальною та викликає необхідність виявлення тенденцій i напрямів розвитку ринку лізингових послуг у структурі фрінансового ринку.

Аналіз останніх досліджень і публікацій. Питання дослідження теоретичних засад організації лізингових відносин вивчали такі вітчизняні науковці, як С. Брус, Н. Внукова, В. Другова, Б. Луців,
Т. Майорова, В. Марцин, В. Міщенко, Р. Саблук, Н. Слав'янська, Г. Холодний, Т. Хомуляк. Однак аспекти формування та розвитку ринку лізингових послуг як системи не отримали належного висвітлення в науковій літературі.

Постановка завдання. Мета статті полягає у вивченні практичних аспектів організації ринку лізингових послуг в Україні. Окремої уваги потребує визначення сучасних тенденцій, основних проблем та подальших перспектив розвитку вітчизняного ринку лізингових послуг. Завданням дослідження $€$ обґрунтування пропозицій нормативно-правового, організаційного та фрінансового впливу на активізацію діяльності учасників лізингового бізнесу.

Виклад основного матеріалу дослідження. Значущою під час формування конкурентоздат- 
ної економіки та пожвавлення результативності виробництва має здатність ринку мобілізувати значні обсяги вільного капіталу та оперувати ними. Йдеться про різноманітність механізмів фрінансування, а також схем надання фрінансових послуг професійними учасниками ринку. Серед таких схем особливо виділяється лізинг як потужний інструмент управління грошовими потоками суб'єктів господарювання.

Через багатогранність лізингових відносин ринок лізингових послуг поєднав елементи ринку реальних активів та фрінансового ринку. Так, якщо йдеться про класичні взаємовідносини між суб'єктами лізингового бізнесу, де посередником є лізингова компанія або комерційний банк, а об'єктами угоди є матеріальні активи (елементи основних фондів), то лізинговий ринок є складовою ринку реальних активів. Однак якщо в процесі реалізації лізингу між суб'єктами виникають кредитні відносини, які характеризують особливості кредитного ринку (ринку банківських позик), або фрінансові відносини за умови організації вендорного фрінансування, то частина лізингових відносин реалізується вже на фрінансовому ринку. Отже, довгострокові фрінансово-кредитні відносини у сорері лізингу транссрормуються у грошові відносини та завершуються на ринку реальних активів.

Згідно 3 даними аналітичного огляду ринку лізингових послуг в Україні дослідження експертів проєкту USAID «Tрансорормація фрінансового сектору» українські малі та середні підприємства недоотримують близько 9,3 млрд. дол. на рік, а серед багатьох причин недофінансування $€$ саме обмеженість стимулів для використання такої альтернативи банківському кредитуванню, як лізингове фрінансування [1, с. 10].

Крім того, у 2013-2015 рр., згідно з рис. 1, 2, спостерігалася тенденція відкладеного попиту на ліквідні активи, тобто машини, обладнання, інвентар, транспортні засоби, програмне забезпечення.

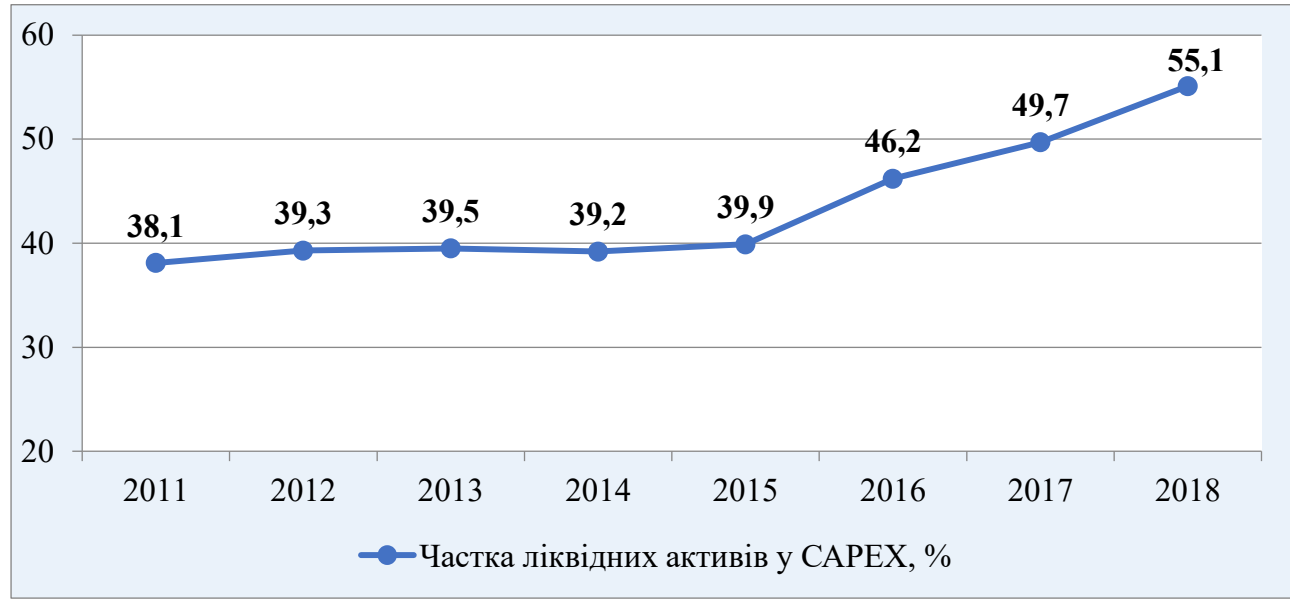

Рис. 1. Частка ліквідних активів в основних засобах за 2011-2018 рр.

Джерело: [2]

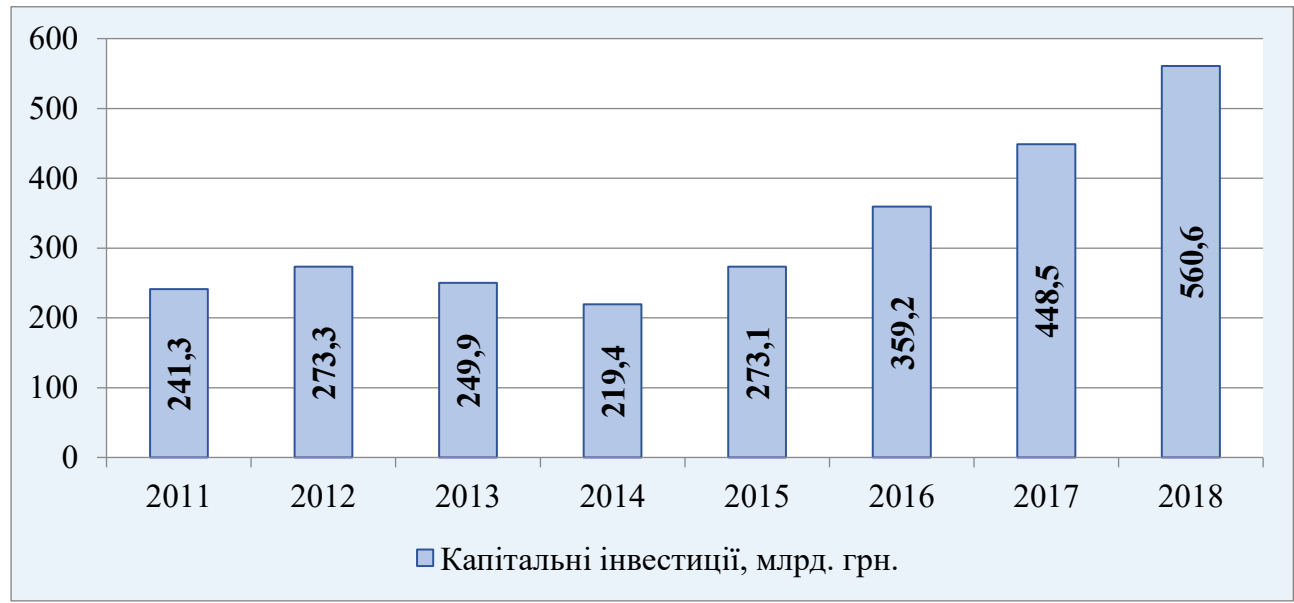

Рис. 2. Капітальні інвестиції за 2011-2018 рр.

Джерело: [2, с. 6] 
Такі активи є фрактично об'єктами лізингу, що дає надію та потенціал для стимулювання розвитку ринку лізингових послуг у подальші роки. 3 економічної точки зору лізинг може стати тим фрінансовим інструментом, який допоможе профрінансувати реновацію застарілих виробничих потужностей та оновлення інфрраструктури в Україні.

щодо ринку лізингових послуг, то маємо справу 3 аналізом діяльності різних учасників ринку, об'єктів ринку, визначенням обсягів та вартості лізингових послуг, які на них реалізуються, їх місткістю, перспективою росту тощо.

Далі більш детально розглянемо діяльність лізингодавців, тобто юридичних осіб та фрінансових компаній, що надають послуги фрінансового лізингу в Україні останніми роками. Так, за підсумком 6 місяців 2019 р., згідно з даними Переліку юридичних осіб, які мають право надавати фрінансові послуги та перебувають на обліку в Нацкомфрінпослуг, в Україні існувало 167 юридичних осіб лізингодавців; до Державного реєстру фрінансових установ станом на 1 липня 2019 р. була внесена інфрормація про 121 установу, що мають чинну ліцензію на право надання послуг з фрінансового лізингу, що на 4,3\% більше, ніж за весь 2018 р. (рис. 3). Сьогодні фрінансовий лізинг здійснюється переважно трьома надавачами, а саме банками, фрінансовими компаніями та юридичними особами, які отримали в Нацкомфрінпослуг ліцензію на здійснення фінансового лізингу.

Економічні виклики минулих років вплинули не лише на темпи розвитку України, але й на лізингову галузь. Так, ринок лізингових послуг повільно відновлюється після різкого зменшення кількості лізингових угод на 40\% у 2015 р. За 2018 р. кількість укладених договорів фрінансового лізингу збільшилася в 1,3 рази, а вартість - у 1,7 разів порівняно $з$ попереднім роком, що свідчить про позитивні тенденції на ринку (табл. 1).

Загалом за результатами 2018 р. фрінансовими установами та лізингодавцями - юридичними особами, які не мають статусу фрінансових установ,

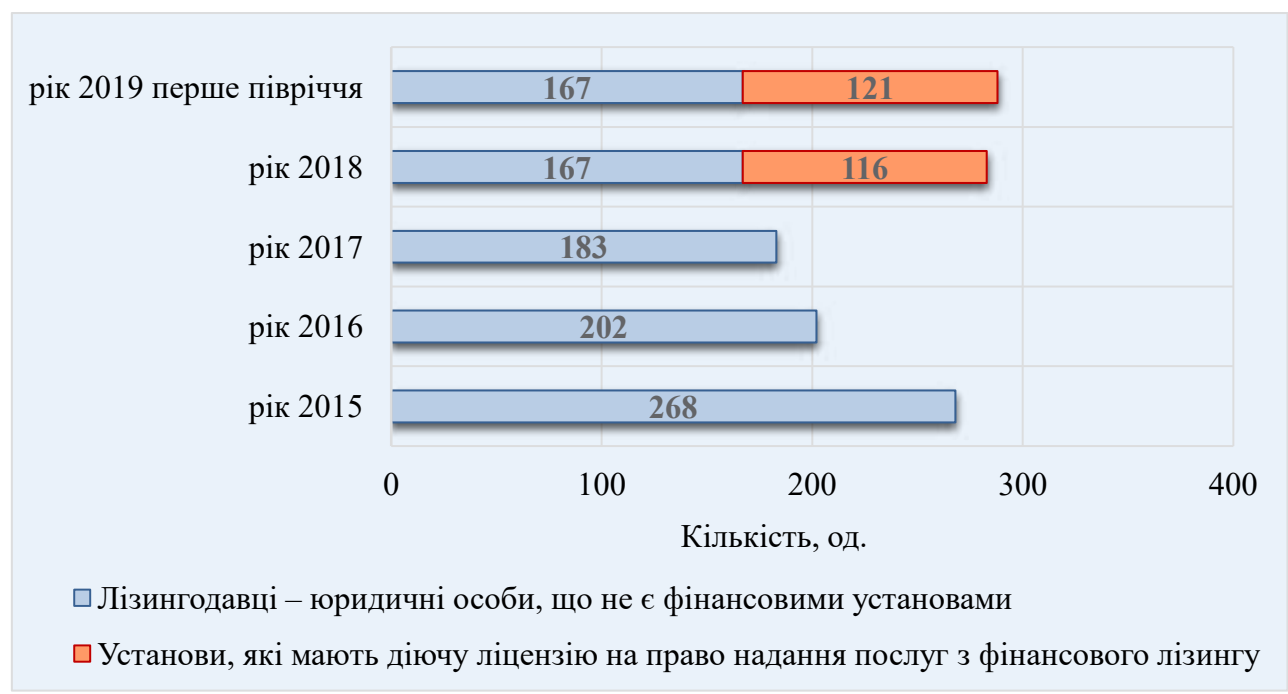

Рис. 3. Кількість лізингодавців, які здійснюють свою діяльність у сорері фрінансового лізингу

Джерело: [2]

Таблиця 1

Вартість договорів фрінансового лізингу та їх кількість за 2015-2018 рр.

\begin{tabular}{|c|c|c|c|c|}
\hline \multirow[b]{2}{*}{ Період } & \multicolumn{2}{|c|}{$\begin{array}{c}\text { Вартість договорів фрінансового лізингу, } \\
\text { млн. грн. }\end{array}$} & \multicolumn{2}{|c|}{ Кількість договорів фрінансового лізингу, од. } \\
\hline & $\begin{array}{c}\text { лізингодавців - } \\
\text { юридичних осіб, які не є } \\
\text { фінансовими установами }\end{array}$ & $\begin{array}{l}\text { фрінансових } \\
\text { установ }\end{array}$ & $\begin{array}{c}\text { лізингодавців - } \\
\text { юридичних осіб, які не є } \\
\text { фінансовими установами }\end{array}$ & $\begin{array}{l}\text { фінансових } \\
\text { установ }\end{array}$ \\
\hline 2014 & 7181,0 & 257,4 & 8940 & 26 \\
\hline 2015 & 6241,4 & 20,2 & 4098 & 21 \\
\hline 2016 & 9755,0 & 67,3 & 9122 & 38 \\
\hline 2017 & 12814,2 & 153,4 & 7699 & 53 \\
\hline 2018 & 21519,3 & 673,8 & 8739 & 1584 \\
\hline $\begin{array}{c}2019 \\
\text { (1 півріччя) } \\
\end{array}$ & 11938,8 & 369,1 & 4637 & 1941 \\
\hline
\end{tabular}

Джерело: побудовано авторами на основі [4, с. 10; 5, с. 8; 6, с. 9] 
але можуть згідно із законодавством надавати фрінансові послуги, було укладено 10323 договори фрінансового лізингу на суму 22,19 млрд. грн. Серед них близько 97\% послуг фрінансового лізингу надано лізингодавцями - юридичними особами, які не є фрінансовими установами, що припадає на 20 найбільших лізингодавців.

Характеризуючи ринок лізингу в Україні за об'єктами лізингу, спостерігаємо, що левову частку в структурі лізингових угод становлять транспортні засоби (легкові та вантажні автомобілі), тобто близько 68\% від загальної вартості договорів фрінансового лізингу, що зумовлено високою ліквідністю такого майна, а також його добре розвиненим вторинним ринком (табл. 2). Крім того, спостерігаємо значну частку договорів сільськогосподарської техніки та обладнання, що становить 23\% від загальної вартості договорів фрінансового лізингу (серед них 50\% становлять трактори, 25\% зернозбиральні комбайни, 25\% - оброблювальна техніка), що можна аргументувати зростанням привабливості аграрного бізнесу для лізингодавців юридичних осіб та фрінансових структур завдяки збільшенню його прибутковості. На інші види техніки, наприклад, у сорерах будівництва, добувної промисловості, металургії, медичної техніки та сорери послуг, припадають лише 19\%.

Така структурованість договорів фрінансового лізингу свідчить про те, що за рахунок лізингу відбувається оновлення тих об'єктів основних засобів, які найбільше цього потребують.

Впродовж 2015-2018 рр. найбільшими споживачами лізингових послуг у країні $€$ транспортна галузь, сільське господарство, сфрера послуг та будівництво (рис. 4). Станом на 30 червня 2019 р. найбільшими лізингоотримувачами стали тран- спортна галузь, де вартість договорів становила 6 743,3 млн. грн. (станом на 30 червня 2018 р. 6 883,9 млн. грн., спад на 2,0\% (140,6 млн. грн.)); сільське господарство, де вартість договорів становила 6 039,6 млн. грн. (станом на 30 червня 2018 р. - 5 960,9 млн. грн., зростання на 1,3\% (78,7 млн. грн.)); сорера послуг, де вартість договорів становила 1610,2 млн. грн. (станом на 30 червня 2018 р. - 1 431,9 млн. грн., зростання на 12,5\% (178,3 млн. грн.)); будівництво, де вартість договорів становила 1 292,7 млн. грн. (станом на 30 червня 2018 р. - 1359,7 млн. грн., спад на 4,9\% (67,0 млн. грн.)). Водночас слаборозвиненим залишається фрінансовий лізинг у харчовій, хімічній, легкій промисловості, машинобудуванні, комп'ютерній та телекомунікаційній сорерах, які понад усе потребують оновлення основних фрондів та забезпечення фрінансування реальних інвестиційних проєктів.

Протягом 2018 р. загальний обсяг джерел фрінансування юридичних осіб - лізингодавців та фрінансових компаній становив 17 930,1 млн. грн., що на 7 512,6 млн. грн., або на 72,1\%, більше, ніж у 2017 р. У першому півріччі 2019 р. загальний обсяг джерел фрінансування юридичних осіб лізингодавців та фрінансових компаній збільшився на 9,0\% порівняно з першим півріччям 2018 р. (табл. 3). Помітною є тенденція зростання авансового платежу за період дослідження, що свідчить про збільшення усвідомлення лізингодавцями ризику надання послуг та їх неготовність брати на себе більший ризик.

У структурі джерел фрінансування лізингових операцій юридичних осіб - лізингодавців найбільші частки мають власний капітал $(31,4 \%$, або 5 300,8 млн. грн.) та кредити банків (26,8\%, або

Вартість договорів фінансового лізингу, укладених за звітний період,

Таблиця 2 за об'єктами лізингу, млн. грн.

\begin{tabular}{|l|c|c|c|c|c|}
\hline \multicolumn{1}{|c|}{ Об'єкти лізингу } & $\mathbf{2 0 1 5}$ p. & $\mathbf{2 0 1 6}$ p. & $\mathbf{2 0 1 7}$ p. & 2018 p. & $\begin{array}{c}\mathbf{2 0 1 9} \text { p. } \\
\text { (перше півріччя) }\end{array}$ \\
\hline Транспорт & 14713,6 & 5715,4 & 6735,7 & 15523,8 & 7765,4 \\
\hline $\begin{array}{l}\text { Комп'ютерна техніка та } \\
\text { телекомунікаційне обладнання }\end{array}$ & 25,4 & 0 & 4,9 & 44,1 & 0,5 \\
\hline Друкарське та поліграфічне обладнання & 46,2 & 0,3 & 20,4 & 9,5 & 4,3 \\
\hline Торговельне обладнання & 243,3 & 27,1 & 6,7 & 2,3 & 2,2 \\
\hline $\begin{array}{l}\text { Техніка та устаткування для } \\
\text { сільгосппідприємств }\end{array}$ & 5736,4 & 3635,5 & 3043,7 & 5123,1 & 3622,7 \\
\hline Будівельне обладнання та техніка & 1553,8 & 330,7 & 1190,0 & 822,9 & 467,6 \\
\hline Обладнання для харчової переробки & 66,7 & 0 & 33,6 & 0,6 & 0 \\
\hline Медичне обладнання & 14,2 & 4,5 & 21,0 & 218,6 & 29,8 \\
\hline Банківське обладнання & 5,2 & 0 & 0 & 0 & 0 \\
\hline Промислове обладнання & 166,0 & 7,8 & 28,8 & 34,6 & 74,8 \\
\hline Будівлі та споруди & 893,0 & 12,1 & 560,9 & 10,5 & 49,7 \\
\hline Інше & 2883,9 & 88,3 & 1322,0 & 941,7 & 290,9 \\
\hline
\end{tabular}

Джерело: складено авторами на основі [5, с.13; 6, с. 12; 7, с. 12] 
4 532,8 млн. грн.). У структурі джерел фрінансування лізингових операцій фрінансових установ лізингодавців на початок 2019 р. також переважали власний капітал (57,5\%), кредити банків $(25,0 \%)$, але зовсім відсутні бюджетні кошти та випуск цінних паперів як джерела фрінансування лізингових послуг, тобто спостерігаються відсутність державних програм, спрямованих на лізинг для малого та середнього бізнесу, й брак іноземного капіталу для розвитку лізингових компаній.
Незважаючи на високий потенціал для розвитку ринку лізингу в Україні, проведене дослідження показує, що такий розвиток може стикнутися 3 гальмівним впливом чинників правового, фрінансово-економічного, організаційного та соціального характеру. Відповідно, проблеми, що стримують розвиток лізингового бізнесу в країні, розподілені на такі:

- проблеми, пов'язані з фрінансовим забезпеченням лізингових угод (істотне погіршення капі-

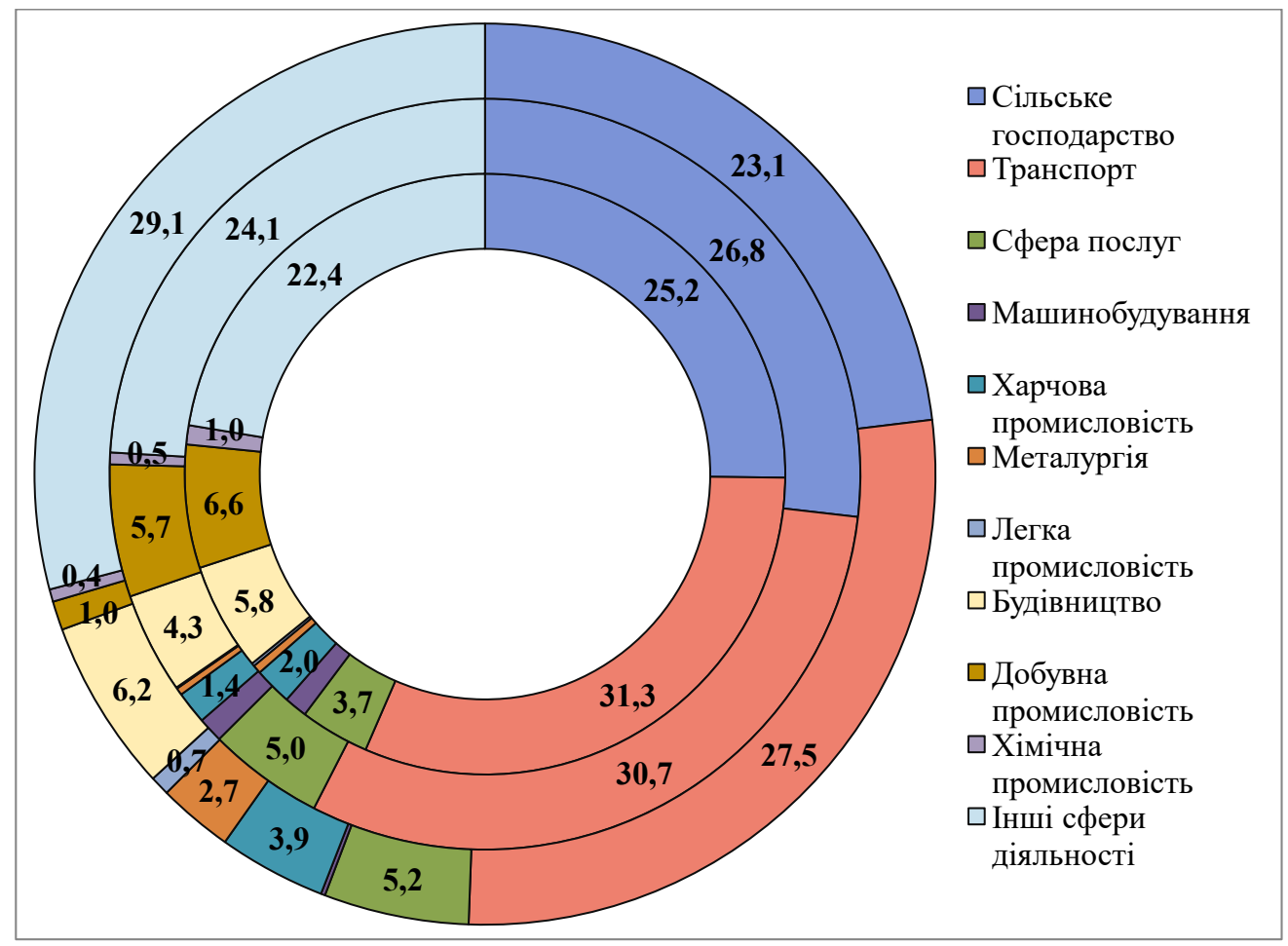

Рис. 4. Розподіл вартості договорів фрінансового лізингу за галузями станом на кінець 2015, 2017, 2018 рр. (2015 р. - внутрішній радіус; 2018 р. - зовнішній радіус діаграми)

Джерело: складено авторами на основі [5; 6; 7]

Таблиця 3

Розподіл джерел фрінансування лізингових операцій, млн. грн.

\begin{tabular}{|c|c|c|c|c|c|c|c|c|c|}
\hline \multirow[b]{2}{*}{ № } & \multirow{2}{*}{$\begin{array}{c}\text { Джерела } \\
\text { фінансування } \\
\text { лізингу }\end{array}$} & \multicolumn{4}{|c|}{$\begin{array}{c}\text { Лізингодавець - юридична особа, } \\
\text { що не є фрінансовою установою }\end{array}$} & \multicolumn{4}{|c|}{$\begin{array}{l}\text { Фінансові установи, що надають } \\
\text { послуги фрінансового лізингу }\end{array}$} \\
\hline & & за 2018 p. & $\begin{array}{l}\text { частка, } \\
\%\end{array}$ & $\begin{array}{c}\text { за перше } \\
\text { півріччя } \\
2019 \text { р. }\end{array}$ & $\begin{array}{l}\text { частка, } \\
\quad \%\end{array}$ & за 2018 p. & $\begin{array}{l}\text { частка, } \\
\quad \%\end{array}$ & $\begin{array}{c}\text { за перше } \\
\text { півріччя } \\
2019 \text { р. } \\
\end{array}$ & $\begin{array}{l}\text { частка, } \\
\quad \%\end{array}$ \\
\hline 1 & Авансовий платіж & 4579,2 & 27,1 & 2927,9 & 30,3 & 115,5 & 11,5 & 41,3 & 14,7 \\
\hline 2 & Власний капітал & 5300,8 & 31,4 & 2895,1 & 30,0 & 576,0 & 57,5 & 10,5 & 3,8 \\
\hline 3 & Кредити банків & 4532,8 & 26,8 & 3041,6 & 31,5 & 251,6 & 25,0 & 81,5 & 29,0 \\
\hline 4 & $\begin{array}{l}\text { Комерційний кредит } \\
\text { постачальників }\end{array}$ & 1,8 & 0,01 & 17,7 & 0,2 & 0,0 & 0,0 & 0,0 & 0,0 \\
\hline 5 & Випуск цінних паперів & 148,8 & 0,9 & 9,6 & 0,1 & 0,0 & 0,0 & 0,0 & 0,0 \\
\hline 6 & $\begin{array}{l}\text { Кошти державного та } \\
\text { місцевого бюджетів } \\
\end{array}$ & 3,5 & 0,02 & 0,0 & 0,0 & 0,0 & 0,0 & 0,0 & 0,0 \\
\hline 7 & Інші джерела & 2360,6 & 13,9 & 767,9 & 7,9 & 60,0 & 6,0 & 147,3 & 52,5 \\
\hline 8 & Всього & 16927,5 & 100,0 & 9659,8 & 100,0 & 1002,6 & 100,0 & 280,6 & 100,0 \\
\hline
\end{tabular}

Джерело: складено авторами на основі [5; 6] 
талізації лізингових компаній, брак власного капіталу у лізингодавців, суттєве збільшення вартості зовнішнього фрінансування з боку кредиторів-нерезидентів, висока вартість гривневих кредитних ресурсів, проблема різкого зростання простроченої заборгованості, дострокового закриття договорів лізингу тощо);

- проблеми у сорері оподаткування лізингових операцій, такі як обмеження можливості віднесення до валових витрат відсотків за кредитами, отриманих від пов'язаних з лізингодавцем банківнерезидентів, відсутність податкових пільг під час фрінансування лізингових операцій;

- недостатня фрінансова стійкість лізингодавців, необхідність створення резервів, а також дефіцит кваліфікованих кадрів у фінансових установах;

- низька фрінансова дисципліна лізингоодержувачів;

- недостатній розвиток та обмежене використання інфраструктури ринку лізингових послуг;

- недостатня поінорормованість підприємств малого та середнього бізнесу, а також фрізичних осіб щодо можливостей та переваг лізингового механізму фрінансування.

Отже, задля усунення перешкод, які гальмують розвиток лізингових послуг в Україні, необхідно:

- вдосконалити нормативно-правову базу у сорері лізингу (впровадити ініціативи протидії шахрайству та зловживанням довірою на ринку, створити правове забезпечення регулювання лізингових послуг з боку НБУ, вдосконалити норми фрінансового моніторингу й звітності лізингодавців);

- уніфікувати державне регулювання й нагляд, скоротити кількість регуляторних і контролюючих органів на вітчизняному ринку фінансових послуг, а також розвивати саморегулювання на ринку;

- розробити та запровадити в дію державну програму підтримки лізингу, в якій, зокрема, слід передбачити створення обласних лізингових центрів, законодавче впровадження податкових пільг, систему реєстрації договорів лізингу, розвиток системи гарантування й страхування предметів лізингу, формування механізму використання інтегрованих фрінансових послуг, підвищення рівня обізнаності населення щодо особливостей та переваг лізингу;

- розробити типові положення щодо організаційної структури лізингових компаній, управління їх ризиками, а також з інших питань, спрямованих на забезпечення їх фрінансової стійкості;

- поліпшити структуру джерел орінансування лізингових операцій, створення умов для запровадження механізму рефінансування портоелів лізингових угод, знизити вартість кредитних ресурсів та нотаріальних послуг тощо.

Висновки 3 проведеного дослідження. Ринок лізингових послуг в Україні вже більше
15 років перебуває на стадії становлення, однак має перспективи для подальшого стрімкого розвитку. Згідно 3 аналітичним повідомленням прес-служби асоціації «Українське об'єднання лізингодавців» попит на послуги лізингових компаній в Україні та обсяги лізингових угод стрімко зростатимуть в найближчі 3-5 років, а обсяг фрінансування українського бізнесу за угодами фрінансового лізингу може як мінімум подвоїтись до 2021 р. Отже, послуги фрінансового лізингу як для малого, так і для середнього бізнесу потребують позиціонування на фрінансовому ринку особливо з огляду на те, що цей інструмент є менш ризикованим, ніж банківський кредит, а його впровадження є можливим через онлайн-продукти. За належної підтримки лізинг може стати гідною альтернативою традиційного кредитування, а також забезпечити оновлення матеріально-технічної бази підприємств, стимулювання науково-технічного прогресу, розвиток пріоритетних галузей економіки та зовнішньоекономічної діяльності.

\section{БІБЛІОГРАФІЧНИЙ СПИСОК:}

1. Краковська А., Вишневський І., Педос Н. Проект USAID «Tрансформація фрінансового сектору». Лізингова галузь в Україні: тенденції та рекомендації для зростання. 2018. Червень. С. 10-11.

2. CAPITAL TIMES: Дослідження розвитку фрінансового лізингу в Україні. Прогноз на 2018-2021 рр. 2018. Вересень. URL: http://uul.com.ua/wp-content/ uploads/2018/10/CT_WM_Leasing_USAID-Conf_ Sep2018-4-1.pdf (дата звернення: 21.11.2019).

3. Інформація про стан і розвиток фрінансових компаній та лізингодавців (основні показники діяльності) // Офіційний веб-сайт Національної комісії, що здійснює державне регулювання у сфрері ринків фрінансових послуг. URL: https://www.nfp.gov.ua/ua/ Informatsiia-pro-stan-i-rozvytok-finansovykh-kompaniilizynhodavtsiv-ta-lombardiv-Ukrainy.html (дата звернення: 19.11.2019).

4. Підсумки діяльності фрінансових компаній, ломбардів та юридичних осіб (лізингодавців) за 2017 р. // Офріційний веб-сайт Національної комісії, що здійснює державне регулювання у сорері ринків фрінансових послуг. URL:https://www.nfp.gov.ua/files/OgliadRinkiv/ FK/OsnPokazn/FK_4\%20\%D0\%BA\%D0\%B2_2017.pdf (дата звернення: 18.11.2019).

5. Підсумки діяльності фрінансових компаній та юридичних осіб (лізингодавців) за 2018 р. // Офріційний веб-сайт Національної комісії, що здійснює державне регулювання у сорері ринків фрінансових послуг. URL: https://www.nfp.gov.ua/files/OgliadRinkiv/FK/FK_IV\%20 kv_2018.pdf (дата звернення: 13.11.2019).

6. Підсумки діяльності фрінансових компаній та юридичних осіб (лізингодавців) за I півріччя 2019 р. // Офріційний веб-сайт Національної комісії, що здійснює державне регулювання у сфрері ринків фрінансових послуг. URL: https://www.nfp.gov.ua/files/ OgliadRinkiv/FK/FK_II\%20kv_2019.pdf (дата звернення: 10.11.2019). 
7. Аналітичний огляд ринку небанківських фінансових послуг України за підсумком 9 місяців 2018 р. // Офіційний веб-сайт національного рейтингового агентства «Рюрик». URL: http://rurik.com.ua/ documents/research/non_ banks_3_2018.pdf (дата звернення 19.11.2019).

\section{REFERENCES:}

1. Krakovska A., Vyshnevskyi I., Pedos N. (2018) Proekt USAID "Transformatsiia finansovoho sektoru". Lizynhova haluz v Ukraini: tendentsii ta rekomendatsii dlia zrostannia, cherven, pp. 10-11. (in Ukrainian)

2. CAPITAL TIMES: Doslidzhennia rozvytku finansovoho lizynhu v Ukraini. Prohnoz na 2018-2021 rr. 2018, veresen. Available at: http://uul.com.ua/wp-content/ uploads/2018/10/CT WM Leasing USAID-Conf Sep2018-4-1.pdf (accessed 21 November 2019).

3. Ofitsiinyi veb-sait Natsionalnoi komisii, shcho zdiisniuie derzhavne rehuliuvannia $u$ sferi rynkiv finansovykh posluh: informatsiia pro stan i rozvytok finansovykh kompanii ta lizynhodavtsiv (osnovni pokaznyky diialnosti). Available at: https://www.nfp.gov.ua/ ua/Informatsiia-pro-stan-i-rozvytok-finansovykh-kompanii-lizynhodavtsiv-ta-lombardiv-Ukrainy.html (accessed 19 November 2019).
4. Ofitsiinyi veb-sait Natsionalnoi komisii, shcho zdiisniuie derzhavne rehuliuvannia u sferi rynkiv finansovykh posluh: Pidsumky diialnosti finansovykh kompanii, lombardiv ta yurydychnykh osib (lizynhodavtsiv) za 2017 r. Available at: https://www.nfp.gov.ua/files/OgliadRinkiv/ FK/OsnPokazn/FK 4\%20\%D0\%BA\%D0\%B2 2017.pdf (accessed 18 November 2019).

5. Ofitsiinyi veb-sait Natsionalnoi komisii, shcho zdiisniuie derzhavne rehuliuvannia u sferi rynkiv finansovykh posluh: Pidsumky diialnosti finansovykh kompanii ta yurydychnykh osib (lizynhodavtsiv) za 2018 r. Available at: https://www.nfp.gov.ua/files/OgliadRinkiv/FK/FK_ IV\%20kv_2018.pdf (accessed 13 November 2019).

6. Ofitsiinyi veb-sait Natsionalnoi komisii, shcho zdiisniuie derzhavne rehuliuvannia u sferi rynkiv finansovykh posluh: Pidsumky diialnosti finansovykh kompanii ta yurydychnykh osib (lizynhodavtsiv) za I pivrichchia 2019 Available at: https://www.nfp.gov.ual files/OgliadRinkiv/FK/FK_II\%20kv_2019.pdf (accessed 10 November 2019).

7. Ofitsiinyi veb-sait natsionalnoho reitynhovoho ahentstva "Riuryk": Analitychnyi ohliad rynku nebankivskykh finansovykh posluh Ukrainy za pidsumkom 9 misiatsiv 2018 r. Available at: http://rurik.com.ua/ documents/research/non_banks_3_2018.pdf (accessed 19 November 2019). 


\section{Liakhova Olena}

Candidate of Economic Sciences, Associate Professor, Senior Lecturer at Department of Corporate Finance and Controlling SHEE "Kyiv National Economic University named after Vadym Hetman"

Urvantseva Svitlana

Candidate of Economic Sciences, Associate Professor, Senior Lecturer at Department of Corporate Finance and Controlling SHEE "Kyiv National Economic University named after Vadym Hetman"

\section{THE UKRAINIAN LEASING SERVICES MARKET DEVELOPMENT}

The purpose of the article. Leasing market plays a significant role in a capital movement, ensures economic renewal and production growth, as well as competition increase in the financial services market. It needs to be mentioned that transformation processes taking place in the leasing market are not unidirectional and unambiguous from the beginning of the reforms till now. A very dynamic nature of those processes necessitates a comprehensive consideration of the leasing market, which makes this topic relevant and demands to identify current trends and possible ways of the leasing services market development in the financial market structure.

Methodology. Common scientific cognition methods were applied in the research process: a systematic approach - for theoretical generalization of the scientists' research results and for revealing the leasing essence as a method of financing investment activity; statistical methods - used to study current trends in the domestic leasing market; analysis and synthesis, logical generalization - to determine factors which hinder the leasing business and substantiation of activation measures for the leasing services market activity in Ukraine.

Results. It is determined that the leasing market combines elements of the real assets market and the financial market, in other words it can be said that long-term financial and credit relations in leasing area are transformed into monetary relations and completed in the real assets market.

While analyzing the Ukrainian market trends of leasing services during 2013-2015, we observe a trend of pent-up demand for liquid assets, i.e. machines, equipment, inventory, vehicles, software. Such assets are leased assets, which created a potential for the leasing market development in the years to come.

Analysis of the economic challenges impact on the leasing industry which had place during several last years and indicators of the leasing services market development for the period from 2015 to 2018 allowed to establish the following trends: a) the vast majority of operations in the leasing market are represented by a financial lease, which is carried out by three main providers: banks, financial companies and legal entities; $b$ ) main sectors of the leasing market are transport, agriculture, services and construction; c) bank loans and own funds prevail among financing sources of lessor activities, at the same time budgetary funds and issue of securities are not actually used as sources of financing for leasing services; d) considering a number of financial leases concluded and their value, a slow market recovery is observed after sharp drop in the number of leases in 2015; e) rapid development of the leasing market and doubling a Ukrainian business financing volume under financial leasing agreements by 2021 is a medium-term prospect.

Practical implications. The study results substantiate measures to activate the leasing services market with their distribution in the following areas: improvement of the legal framework in the leasing sphere, reduction of the number of regulatory and supervisory bodies in the domestic market of financial services, unification of state regulation and supervision, development and implementation of the state leasing program, development of typical provisions for organizational structure of leasing companies and managing their risks, improving the structure of financing sources for leasing operations.

Value/originality. The study examines the leasing services market, which combines elements of the real assets market and financial market. The main indicators of development and trends of the leasing services market are analyzed, the prospects for its further activation in Ukraine are determined. 